\title{
Avaliação da sensibilidade da cultura de leite do tanque para isolamento de agentes contagiosos da mastite bovina ${ }^{1}$
}

\author{
Maria Aparecida V. P. Brito ${ }^{2}$, José Renaldi F. Brito ${ }^{2}$, Heloiza Maria de Souza ${ }^{3}$ e Otacílio \\ Lopes Vargas ${ }^{3}$
}

\begin{abstract}
Brito M.A.V.P., Brito J.R.F., Souza H.M. \& Vargas O.L. 1998. [Evaluation of the sensitivity of bulk tank milk cultures for the isolation of contagious bovine mastitis pathogens.] Avaliação da sensibilidade da cultura de leite do tanque para isolamento de agentes contagiosos da mastite bovina. Pesquisa Veterinária Brasileira 18(1):39-44. Embrapa-Centro Nacional de Pesquisa de Gado de Leite, Juiz de Fora, MG 36038-330, Brazil.

Samples of bulk tank milk from 33 herds were collected at the dairy processing plant and cultured, as a means of detecting specific (contagious) bovine mastitis pathogens. Somatic cell counts (SCC) were made on a Fossomatic 90 . Two and three weekly consecutive samples were obtained from 13 and 12 herds, respectively. Only one sample was examined from eight herds. Three daily consecutive samples of bulk milk and individual quarter samples from all lactating cows from four herds (A, B, C and D) were also examined. Milk from individual quarters were cultured on blood agar, while tank milk samples were cultured on TKT, Mannitol Salt, MacConkey agars and Sabouraud containing chloramphenicol. Staphylococcus aureus was recovered from 26 of the 33 herds sampled in the dairy processing plant. Nine of these samples also contained Streptococcus agalactiae. Nine herds had SCC above 500,000 $\mathrm{ml}^{-1}$. The remaining 23 herds had SCC levels below 400,000 ml-1. S. aureus and S. agalactiae were isolated from five of the nine herds with high SCC, S. agalactiae from one and S. aureus from three. Six herds had SSC below $200,000 \mathrm{ml}^{-1}$. S. aureus and S. agalactiae were isolated from one, S. aureus from three, while the other two were negative for both pathogens. The results of herds A, B, C and D sampled at the farms showed that $S$. aureus was isolated from $1.8 \%, 19.2 \%, 17.0 \%$ and $8.4 \%$ of the animals and $0.9 \%, 5.9 \%, 5.4 \%$ and $2.2 \%$ of the mammary quarters, respectively. S. agalactiae was isolated from herds $\mathrm{A}, \mathrm{C}$ and $\mathrm{D}$. Within these herds the percentages of isolation were, respectively, $1.8 \%$, $10.6 \%$ and $8.4 \%$ for the cows and $0.46 \%, 3.8 \%$ and $3.7 \%$ for the mammary quarters. S. aureus was recovered from all three bulk tank cultures from herds A, B and D. Only the third sample from herd C was positive for S. aureus. S. agalactiae was recovered from all samples collected from herd D, two samples from herd $C$ and one sample from herd $A$. Coliforms were isolated from all tank samples from herds A, B, C and D and from all but one sample collected in the processing plant. Yeasts were recovered from 16 herds sampled at the processing plant and from all tank samples from herds A, B, C, and D. Neither coliforms or yeasts were isolated from the individual animals of herds A, B, C and D. These findings indicate that the milk was contaminated during or after milking, probably due to deficient hygiene and cleaning procedures. The analysis of the bulk tank milk cultures showed that the test was sensitive enough to detect contagious mastitis pathogens. The sensitivity of the test increased when more than two consecutive samples were examined.
\end{abstract}

INDEX TERMS: Bovine mastitis, bulk tank cultures, microbiological diagnosis, contagious pathogens, Staphylococcus aureus, Streptococcus agalactiae, somatic cell counts.

\footnotetext{
${ }^{1}$ Aceito para publicação em 8 de dezembro de 1997.

Trabalho realizado com apoio financeiro do Conselho Nacional de Desenvolvimento Científico e Tecnológico (CNPq, Projeto 530.190/93-1).

${ }^{2}$ Embrapa-CNPGL, Rua Eugênio do Nascimento 610, Juiz de Fora, MG 36038330. Bolsistas do CNPq; e-mail do primeiro autor: kbrito@artnet.com.br.

${ }^{3}$ Centro de Pesquisa e Ensino Instituto de Laticínios "Cândido Tostes" da Epamig, Rua Tenente Freitas 116, Juiz de Fora, MG 36045-560; e-mail vargas@nutecnet.com.br.
}

RESUMO.- Amostras de leite total (leite do tanque) de 33 rebanhos foram coletadas na plataforma de recepção da indústria laticinista e cultivadas para detectar patógenos específicos (contagiosos) da mastite. Foi feita a contagem de células somáticas (CCS) das amostras utilizando o equipamento Fossomatic 90. Em 13 e 12 rebanhos avaliaram-se duas e três amostras semanais consecutivas, respectivamente, e em oito avaliou-se apenas uma. Foram também examinadas três amos- 
tras diárias consecutivas do leite do tanque e amostras dos quartos mamários individuais, coletadas na própria fazenda, de todas as vacas em lactação de quatro rebanhos (A, B, C e D). As amostras de leite dos quartos mamários individuais foram cultivadas em ágar sangue e as amostras do tanque, em placas de TKT, Sal Manitol, MacConkey e Sabouraud contendo cloranfenicol. Dos 33 rebanhos cujas amostras foram obtidas na plataforma de recepção da indústria, isolou-se Staphylococcus aureus de 26, nove desses em associação com Streptococcus agalactiae e em três rebanhos isolou-se somente $S$. agalactiae. Nove rebanhos tiveram CCS acima de 500.000 $\mathrm{ml}^{-1}$ e 21 , abaixo de $400.000 \mathrm{ml}^{-1}$. Em cinco dos nove rebanhos com CCS acima de $500.000 \mathrm{ml}^{-1}$ foram isolados $S$. aureus e $S$. agalactiae, em três, apenas $S$. aureus e em um, apenas $S$. agalactiae. Seis rebanhos apresentaram CCS abaixo de 200.000 $\mathrm{ml}^{-1}$; de um deles foram isolados $S$. aureus e $S$. agalactiae, de três, $S$. aureus e os outros dois foram negativos para estes dois patógenos. Os resultados encontrados nos quatro rebanhos cujas amostras foram coletadas na própria fazenda mostraram que $S$. aureus foi isolado nas seguintes porcentagens dos animais: $1,8 \%, 19,2 \%, 17,0 \%$ e $8,4 \%$ e dos quartos mamários: $0,9 \%, 5,9 \%, 5,4 \%$ e $2,2 \%$, respectivamente, para os rebanhos A, B, C e D. S. agalactiae foi isolado dos rebanhos A, C e D. Nestes três rebanhos, as porcentagens de isolamento foram, respectivamente, $1,8 \%, 10,6 \%$ e $8,4 \%$ para as vacas e $0,46 \%$, $3,8 \%$ e $3,7 \%$ para os quartos mamários. $S$. aureus foi isolado de todas três amostras do tanque dos rebanhos A, B e D. Somente a terceira amostra do rebanho $C$ foi positiva para $S$. aureus. $S$ agalactiae foi recuperado de todas as amostras do rebanho $\mathrm{D}$, duas do rebanho $\mathrm{C}$ e de uma do rebanho $\mathrm{A}$. Todas as amostras do tanque dos rebanhos $\mathrm{A}, \mathrm{B}, \mathrm{C}$ e $\mathrm{D}$ apresentaram contaminação com coliformes e somente uma das amostras coletadas na plataforma de recepção da indústria foi negativa para coliformes. Leveduras foram isoladas de 16 amostras coletadas na indústria e de todas amostras do tanque dos rebanhos A, B, C e D. Não foram isolados coliformes ou leveduras dos quartos mamários dos animais destes rebanhos, sugerindo que ocorreu contaminação do leite durante ou após a ordenha, provavelmente devido a deficiências nos processos de limpeza e higienização. A análise dos resultados das culturas do leite do tanque mostrou que o exame foi específico para detectar os patógenos contagiosos da mastite. A sensibilidade do teste aumentou quando se examinaram mais de duas amostras consecutivas.

TERMOS DE INDEXAÇÃO: Mastite bovina, cultura do leite total da fazenda, diagnóstico microbiológico, patógenos contagiosos, Staphylococcus aureus, Streptococcus agalactiae, contagem de células somáticas.

\section{INTRODUÇÃO}

A cultura de amostras de leite de quartos mamários individuais é usada para determinar a presença de infecção na glândula mamária de vacas leiteiras (Bramley et al. 1996, Sears et al. 1993). Embora de grande utilidade para o diagnóstico e controle da mastite bovina, este processo apresenta como limitação o grande número de amostras que precisam ser examinadas, principalmente quando se faz acompanhamen- to de rebanhos e se necessita avaliar amostras repetidas vezes.

Uma alternativa aos exames individuais é a cultura de amostras do leite total do rebanho (Farnsworth 1993, Godkin \& Leslie 1993), que tem sido usada para o isolamento de patógenos específicos, especialmente os patógenos contagiosos da mastite: Staphylococcus aureus e Streptococcus agalactiae (González et al. 1986, Bartlett et al. 1991, Godkin \& Leslie 1993).

Os microrganismos encontrados no leite total do rebanho originam-se dos úberes infectados, da superfície dos úberes e das tetas, ou de uma variedade de outras fontes do ambiente da fazenda (Godkin \& Leslie, 1993). A presença de S. agalactiae em amostras de leite do tanque indica que ele está sendo eliminado a partir de quartos mamários, pois o único reservatório deste microrganismo é o úbere infectado (Oz et al. 1985, Bartlett \& Miller 1993, Godkin \& Leslie 1993). No caso de $S$. aureus, embora possa ser isolado de diferentes locais em um rebanho, a principal fonte de eliminação no leite são as glândulas mamárias infectadas (Roberson et al. 1994). Portanto, S. aureus isolado de amostras do leite do tanque é também considerado como originário de infecção intramamária (Bartlett et al. 1993, Godkin \& Leslie 1993).

Bactérias do ambiente como Streptococcus uberis, Streptococcus dysgalactiae, Streptococcus bovis, coliformes e leveduras podem estar presente no leite do tanque como resultado de infecção intramamária ou, mais comumente, devido à contaminação não específica do leite (González et al. 1986, Hogan et al. 1986). O isolamento desses agentes do leite do tanque não pode ser considerado como sendo originário das glândulas mamárias.

O objetivo deste trabalho foi verificar a presença dos agentes contagiosos da mastite, $S$. aureus e $S$. agalactiae, em rebanhos leiteiros por meio da cultura do leite do total (leite do tanque). Paralelamente foi monitorada a presença dos microrganismos do ambiente: coliformes e leveduras. Os resultados são discutidos considerando-se a viabilidade de utilização desta técnica para acompanhamento de rebanhos nas condições brasileiras.

\section{MATERIAL E MÉTODOS}

Coleta de amostras do leite total da fazenda

Foram examinadas amostras do leite total de 33 rebanhos, na região da Zona da Mata de Minas Gerais, obtidas na plataforma de recepção da indústria e de outros quatro rebanhos, denominados $\mathrm{A}$, $\mathrm{B}, \mathrm{C}$ e D, tomadas na própria fazenda. Na indústria, as amostras de leite foram coletadas imediatamente após a reunião de todos os latões de cada rebanho para a pesagem. O leite foi totalmente homogeneizado e um volume de $20,0 \mathrm{ml}$ foi retirado com pipeta esterilizada, da parte superior e central do tanque e acondicionado em frasco de vidro esterilizado. Em oito dos 33 rebanhos foi coletada uma amostra, em 13 e em 12 rebanhos foram coletadas duas e três amostras semanais consecutivas, respectivamente. Foi feita a contagem de células somáticas utilizando um contador automático Fossomatic 90 de uma amostra de cada rebanho.

Dos rebanhos A, B, C e D foram tomadas três amostras, em três dias consecutivos. Nos rebanhos A, B e C, a ordenha era do tipo macânica em sistema de circuito fechado. Volumes de $20 \mathrm{ml}$ de leite 
foram retirados com pipeta esterilizada, da parte central e superior do tanque, imediatamente após a ordenha, quando o leite era homogeneizado para o resfriamento. No rebanho $\mathrm{D}$, a ordenha era mecânica utilizando o sistema de balde ao pé. Neste, após completa homogeneização do leite de cada latão, volumes de $4,0 \mathrm{ml}$ foram retirados e reunidos em um frasco único.

Após a coleta de todas as amostras, o leite foi acondicionado em frascos de vidro esterilizados, colocados, imediatamente, em recipiente com gelo e levados ao laboratório para exame microbiológico.

Coleta de amostras de leite de quartos mamários individuais

Na semana anterior à primeira coleta do leite do tanque dos rebanhos A, B, C e D, foram coletadas amostras de leite de todos os quartos mamários das vacas em lactação, para exame microbiológico. As amostras foram obtidas imediatamente antes da ordenha, após cuidadosa anti-sepsia das tetas com álcool a $70 \%$. Os jatos de leite foram coletados diretamente em frascos estéreis, que foram colocados em caixas de isopor com gelo e encaminhados imediatamente ao laboratório para processamento das amostras (Harmon et al. 1990).

Exames microbiológicos das amostras do leite total dos rebanhos

As amostras do leite total dos rebanhos foram semeadas nos seguintes meios de cultura seletivos: ágar TKT (Merck), ágar sal manitol (Biobrás), ágar MacConkey (Oxoid) e ágar Sabouraud (Biobrás) com $0,1 \mathrm{mg}$ de cloranfenicol por $\mathrm{ml}$. As amostras dos rebanhos A, B, $C$ e $D$ foram diluídas a $1 / 10$ e $1 / 100$. Volumes de $0,1 \mathrm{ml}$ do leite não diluído e de cada diluição foram semeados em duplicata nos meios citados acima. As amostras coletadas na indústria foram semeadas sem diluição, em volumes de $0,1 \mathrm{ml}$, usando-se também duas placas por amostra.

As leituras das placas foram feitas após 24 e 48 horas de incubação a $37^{\circ} \mathrm{C}$. Colônias com características culturais de S. agalactiae no ágar TKT (azuladas, brilhantes, com halo hemolítico) foram identificadas pela reação positiva nos testes de CAMP (Christie, Atkins e Munch-Peterson), hidrólise do hipurato de sódio, crescimento variável em meio contendo $6,5 \%$ de $\mathrm{NaCl}$ e reação negativa no teste de hidrólise da esculina. Para facilitar identificação das colônias de S. agalactiae no ágar TKT, as placas, após 24 e 48 horas de incubação, foram examinadas sob luz ultavioleta $(365 \mathrm{~nm})$. Nessas condições, a esculina fluoresce e as colônias que hidrolisam a esculina aparecem escuras (Higgs \& Bramley, 1981).

Colônias amarelas e com halo amarelo nas placas de ágar sal manitol foram posteriormente identificadas como $S$. aureus pela produção de coagulase, reação fermentativa no meio de Hugh \& Leifson e produção de acetoína. Os testes usados para a identificação de $S$. agalactiae e $S$. aureus foram selecionados de acordo com Harmon et al. (1990) e executados de acordo com Cowan \& Steel (1974). A identificação das leveduras foi feita por meio de esfregaços corados pela técnica de Gram de todas as colônias presentes nas placas de ágar Sabouraud e dos coliformes pela presença de colônias fermentadoras da lactose nas placas de ágar MacConkey.

Exame microbiológico das amostras de leite dos quartos mamários individuais

Volumes de $10 \mu \mathrm{l}$ de cada amostra foram semeados com alça calibrada e descartável (Nunc, INC) em cada quadrante de uma placa de ágar sangue contendo $5 \%$ de sangue desfibrinado de carneiro, de acordo com as recomendações de Harmon et al. (1990).

A identificação de $S$. aureus e $S$. agalactiae foi feita de modo semelhante à descrita para as amostras do tanque. As amostras de Staphylococcus que não produziram coagulase foram identificadas como Staphylococcus coagulase negativos (SCN) e os estreptococos não identificados como $S$. agalactiae foram classificados como Streptococcus sp. esculina positivos (ESCPOS). Foram classificadas como difteróides as bactérias com as seguintes características: colônias pequenas, circulares, esbranquiçadas ou cremosas, apresentando a superfície rugosa, com 1 a $2 \mathrm{~mm}$ de diâmetro, visíveis somente após 48 horas de incubação, encontradas nas áreas mais gordurosas onde se semeia o leite, não produtoras de hemólise no ágar sangue e que apresentavam a reação de catalase positiva. $O$ exame dos esfregaços dessas culturas pelo método de Gram evidenciaram bastonetes Gram positivos pequenos, pleomórficos e não esporulados (Harmon et al., 1990).

\section{RESULTADOS}

Os resultados dos exames das amostras do leite total dos rebanhos coletadas na indústria de processamento, são apresentados nos Quadros 1, 2 e 3. Nos rebanhos onde foi coletada somente uma amostra (Quadro 1) S. aureus foi isolado de seis. Em quatro destes, também foi isolado $S$. agalactiae. Nos 13 rebanhos onde foram feitas duas coletas semanais conse-

Quadro 1. Número de isolamentos positivos para Staphylococcus aureus, Streptococcus agalactiae, leveduras e coliformes em uma amostra do leite total de oito rebanhos, obtida na plataforma de recepção da indústria

\begin{tabular}{ccccccc}
\hline \multirow{2}{*}{$\begin{array}{c}\text { Rebanhos } \\
\text { examinados }\end{array}$} & \multicolumn{5}{c}{ Número de amostras positivas em uma coleta } & \multicolumn{2}{c}{\begin{tabular}{c}
$\mathrm{CCS} \mathrm{ml}^{-1}$ \\
\cline { 2 - 5 }
\end{tabular}} & S. aureus & S. agalactiae & Leveduras & Coliformes & (x 1000) \\
\hline 01 & + & + & + & + & 469 \\
02 & + & + & - & - & 133 \\
03 & - & - & - & + & 140 \\
04 & + & - & - & + & 311 \\
05 & - & + & - & + & 293 \\
06 & + & - & - & + & 39 \\
07 & + & + & + & + & 578 \\
08 & + & - & - & + & 532
\end{tabular}

Quadro 2. Número de isolamentos positivos para Staphylococcus aureus, Streptococcus agalactiae, leveduras e coliformes em duas coletas semanais consecutivas de amostras do leite total de 13 rebanhos, coletadas na plataforma de recepção da indústria. A contagem de células somáticas (CCS) se refere à primeira amostra coletada

\begin{tabular}{cccccc}
\hline \multirow{2}{*}{$\begin{array}{c}\text { Rebanhos } \\
\text { examinados }\end{array}$} & \multicolumn{2}{c}{ Número de amostras positivas em duas coletas } & \multirow{2}{c}{$\begin{array}{c}\mathrm{CS} \mathrm{m}^{-1} \\
\text { (x 1000) }\end{array}$} \\
\cline { 2 - 5 } & S. aureus & S. agalactiae & Leveduras & Coliformes & \\
\hline 01 & 1 & 2 & 1 & 2 & 713 \\
02 & 0 & 0 & 1 & 2 & 363 \\
03 & 2 & 0 & 0 & 2 & 442 \\
04 & 2 & 0 & 0 & 2 & 367 \\
05 & 1 & 1 & 1 & 2 & 279 \\
06 & 0 & 2 & 1 & 2 & 383 \\
07 & 1 & 0 & 1 & 2 & 126 \\
08 & 2 & 0 & 0 & 2 & 319 \\
09 & 2 & 0 & 0 & 2 & 277 \\
10 & 0 & 1 & 0 & 2 & 917 \\
11 & 1 & 0 & 1 & 2 & 259 \\
12 & 0 & 0 & 1 & 2 & 50 \\
13 & 2 & 0 & 0 & 2 & 221
\end{tabular}


Quadro 3. Número de isolamentos positivos para Staphylococcus aureus, Streptococcus agalactiae, leveduras e coliformes em três coletas semanais consecutivas de amostras do leite total de 12 rebanhos, coletadas na plataforma de recepção da indústria. A contagem de células somáticas (CCS) se refere à primeira amostra coletada

\begin{tabular}{ccccccc}
\hline \multirow{2}{*}{$\begin{array}{c}\text { Rebanhos } \\
\text { examinados }\end{array}$} & \multicolumn{2}{c}{ Número de amostras positivas em três coletas } & \multirow{2}{*}{$\begin{array}{c}\text { CCS } \mathrm{ml}^{-1} \\
\text { (x 1000) }\end{array}$} \\
\cline { 2 - 4 } & S. aureus & S. agalactiae & Leveduras & Coliformes & (x) \\
\hline 01 & 1 & 0 & 2 & 2 & 142 \\
02 & 3 & 3 & 3 & 1 & 521 \\
03 & 1 & 0 & 0 & 2 & 257 \\
04 & 1 & 2 & 0 & 3 & 719 \\
05 & 1 & 0 & 0 & 3 & 333 \\
06 & 2 & 0 & 0 & 3 & 401 \\
07 & 0 & 0 & 1 & 3 & 285 \\
08 & 1 & 0 & 0 & 3 & 915 \\
09 & 3 & 3 & 1 & 3 & 985 \\
10 & 2 & 0 & 1 & 3 & 230 \\
11 & 1 & 0 & 1 & 3 & 887 \\
12 & 1 & 1 & 2 & 3 & 221
\end{tabular}

cutivas (Quadro 2), nove amostras foram positivas para $S$. aureus, todas identificadas na primeira coleta. Cinco destas foram positivas também na segunda coleta. S. agalactiae foi isolado de quatro destes 13 rebanhos, sendo três amostras positivas na primeira coleta e uma somente na segunda. Dos 12 rebanhos com três coletas semanais consecutivas, $S$. aureus foi isolado em 11 (Quadro 3). Desses isolamentos, somente seis foram positivos na primeira coleta. Na segunda foram identificados mais dois rebanhos positivos e três rebanhos somente foram positivos na terceira. Dentre os quatro rebanhos positivos para $S$. agalactiae, dois foram identificados na primeira coleta, enquanto os outros dois foram positivos somente na segunda.

Considerando todos os 33 rebanhos, em $29(87,9 \%)$ foram isolados agentes contagiosos da mastite. Em nove deles $(27,3 \%)$, isolaram-se $S$. aureus e $S$. agalactiae, em 17 (51,5\%) isolou-se somente $S$. aureus e em três $(9,1 \%)$, somente $S$. agalactiae. Em somente uma amostra de um rebanho não foram encontrados coliformes. Leveduras foram isoladas de amostras de 16 rebanhos.

Quadro 4. Distribuição dos 33 rebanhos amostrados na plataforma de recepção da indústria laticinista com relação à contagem de células somáticas (CCS) e aos patógenos contagiosos da mastite, Staphylococcus aureus e Streptococcus agalactiae

\begin{tabular}{lccccc}
\hline \multicolumn{7}{c}{$\mathrm{CCS} \mathrm{ml}^{-1}$} & $\begin{array}{c}\text { S. aureus }+ \\
\text { S. agalactiae }\end{array}$ & \multicolumn{2}{c}{ S. aureus S. agalactiae Negativos } & Total \\
\hline${ }^{3} 500.000$ & $5(55,6)^{\mathrm{a}}$ & $3(33,3)$ & $1(11,1)$ & - & $9(27,3)$ \\
$500.000-400.001$ & $1(33,3)$ & $2(66,7)$ & - & - & $3(9,1)$ \\
$400.000-300.001$ & - & $4(66,7)$ & $1(16,7)$ & $1(16,7)$ & $6(18,2)$ \\
$300.000-200.000$ & $5(55,6)$ & $2(22,2)$ & $1(11,1)$ & $1(11,1)$ & $9(27,3)$ \\
$<200.000$ & $1(16,7)$ & $3(50)$ & - & $2(33,3)$ & $6(18,2)$ \\
& & & & & \\
Total & $12(36,4)$ & $14(42,4)$ & $3(9,1)$ & $4(12)$ & $33(100)$
\end{tabular}

a Os números entre parêntesis se referem às porcentagens dos totais.
As placas de cultura usadas para isolamento de $S$. agalactiae (ágar TKT) apresentaram contaminação com colônias de Streptococcus sp. esculina positivas, evidenciadas pelo escurecimento do meio em torno das colônias. Em algumas amostras foi maior a contaminação e, conseqüentemente, maior a zona de escurecimento do meio. A visualização das colônias sob luz ultra-violeta facilitou a seleção das bactérias que não hidrolisam a esculina para identificação posterior. As placas para isolamento de $S$. aureus apresentaram, em geral, menor crescimento bacteriano e pouca contaminação com outros Staphylococcus.

Os resultados das contagens de células somáticas (CCS) estão sumarizados no Quadro 4. Seis rebanhos apresentaram contagens abaixo de $200.000 \mathrm{ml}^{-1}$; em um destes rebanhos foram isolados $S$. aureus e $S$. agalactiae, em três, $S$. aureus e dois foram negativos para estes dois agentes. Nove rebanhos apresentaram contagens acima de $500.000 \mathrm{ml}^{-1}$. Em cinco destes, foram isolados $S$. aureus e $S$. agalactiae, em três isolou-se apenas $S$. aureus e em um, apenas $S$. agalactiae. Vinte e um rebanhos $(63,6 \%)$ apresentaram contagens de células somáticas $£ 400.000 \mathrm{ml}^{-1}$. Em dezessete deles foram isolados agentes contagiosos da mastite, sendo que em três, $S$. aureus e $S$. agalactiae, em doze e em dois, $S$. aureus e $S$. agalactiae, respectivamente (Quadro 1, 2 e 3).

Os resultados dos exames dos quatro rebanhos onde se examinaram amostras de leite de todos os quartos mamários individuais e três amostras diárias consecutivas do leite do tanque são apresentados nos Quadros 5 e 6 . Todas as culturas das amostras do tanque dos quatro rebanhos foram positivas para $S$. aureus nas três coletas, com exceção do rebanho $\mathrm{C}$, em que somente a amostra da terceira coleta foi positiva. Foi possível isolar S. agalactiae das três amostras do rebanho $\mathrm{D}$, de duas do rebanho $\mathrm{C}$ e de apenas uma do rebanho A (Quadro 5). Todas as amostras do tanque apresentaram contaminação com coliformes e leveduras, enquanto não se isolaram esses microrganismos dos quartos individuais.

Quadro 5. Resultados de isolamento de Staphylococcus aureus e Streptococcus agalactiae em três amostras diárias consecutivas do leite do tanque e de amostras obtidas de todos os quartos mamários individuais dos rebanhos A, B, C e D

\begin{tabular}{|c|c|c|c|c|c|c|}
\hline \multirow{2}{*}{$\begin{array}{r}\text { Rebanhos } \\
\text { (total de } \\
\text { animais) }\end{array}$} & \multirow[t]{2}{*}{ Bactérias } & \multirow{2}{*}{$\begin{array}{l}\text { No. animais } \\
\text { infectados no } \\
\text { rebanho (\%) }\end{array}$} & \multirow{2}{*}{$\begin{array}{c}\text { No. quartos } \\
\text { infectadas no } \\
\text { rebanho (\%) }\end{array}$} & \multicolumn{3}{|c|}{ Amostras do tanque } \\
\hline & & & & $1^{\mathrm{a}}$ & $2^{\mathrm{a}}$ & $3^{a}$ \\
\hline \multirow[t]{2}{*}{ A (55) } & S. aureus & $01(1,8 \%)$ & $02(0,9 \%)$ & + & + & + \\
\hline & S. agalactiae & $01(1,8 \%)$ & $01(0,46 \%)$ & - & + & - \\
\hline \multirow[t]{2}{*}{ B (52) } & S. aureus & $10(19,2 \%)$ & $12(5,9 \%)$ & + & + & + \\
\hline & S. agalactiae & 0 & 0 & - & - & - \\
\hline \multirow[t]{2}{*}{ C (47) } & S. aureus & $08(17,0 \%)$ & $10(5,4 \%)$ & - & - & + \\
\hline & S. agalactiae & $05(10,6 \%)$ & $07(3,8 \%)$ & + & - & + \\
\hline \multirow[t]{2}{*}{$\mathrm{D}(119)$} & S. aureus & $10(8,4 \%)$ & $10(2,2 \%)$ & + & + & + \\
\hline & S. agalactiae & $10(8,4 \%)$ & $17(3,7 \%)$ & + & + & + \\
\hline
\end{tabular}

a Os sinais positivo e negativo indicam isolamento e não-isolamento de $S$. aureus e $S$. agalactiae. 
Quadro 6. Número de bactérias isoladas de amostras de quartos mamário individuais das vacas em lactação dos rebanhos A, B, C e $D$, onde foram feitas culturas do leite do tanque

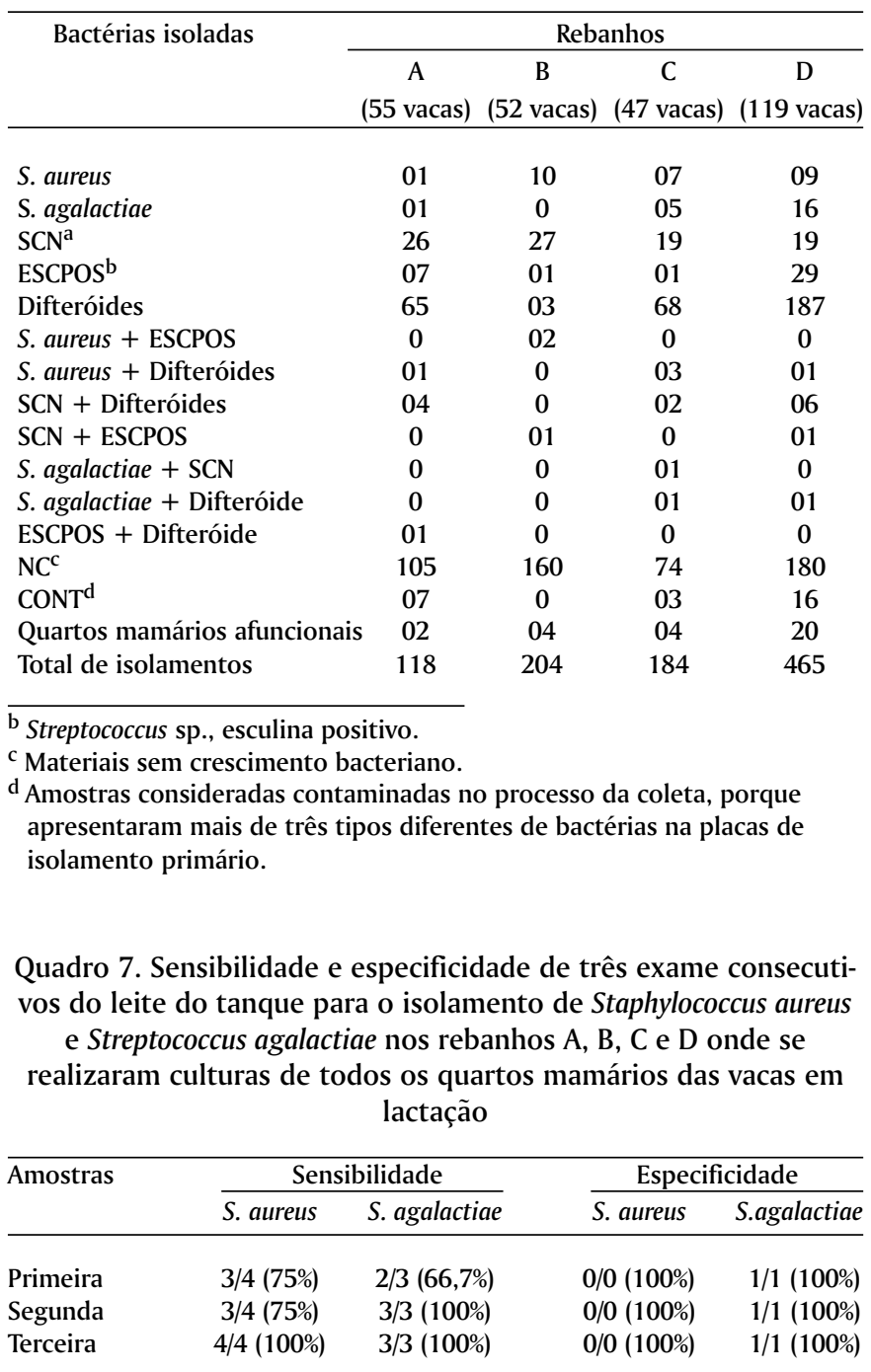

Dos exames dos quartos mamários individuais, $S$. aureus foi isolado nas seguintes porcentagens dos animais: $1,8 \%(\mathrm{~A})$; $19,2 \%(B) ; 17,0 \%(C)$ e $8,4 \%$ (D) e dos quartos mamários: $0,9 \%$ (A); 5,9\% (B); 5,4\% (C) e 2,2\% (D). Os rebanhos A, C e D apresentaram infecção por $S$. agalactiae, respectivamente, nas seguintes porcentagens dos animais: $1,8 \% ; 10,6 \%$ e $8,4 \%$ e dos quartos mamários: $0,46 \% ; 3,8 \%$ e $3,7 \%$, respectivamente (Quadro $5)$. Os demais microrganismos isolados desses animais são apresentados no Quadro 6.

\section{DISCUSSÃO E CONCLUSÕES}

Os resultados mostraram que o exame microbiológico do leite total do rebanho, usando meios de cultura seletivos, é um método sensível e específico para verificar a presença da infecção por $S$. aureus e $S$. agalactiae no rebanho. A sensibilidade, definida como a habilidade do teste identificar corretamente os rebanhos infectados a especificidade, definida como a habilidade do teste identificar corretamente os nãoinfectados (Martin et al. 1994), obtidas para os rebanhos A, B, C e D, onde se examinaram todos os quartos mamários dos animais em lactação, são mostradas no Quadro 7. No rebanho A foram detectados apenas dois quartos mamários infectados com $S$. aureus e todas as três amostras do tanque foram positivas para este agente. $S$. agalactiae só foi isolado de um quarto mamário no rebanho A e somente uma das três amostras do tanque foi positiva. No rebanho $\mathrm{C}$, onde somente cinco vacas estavam infectadas com $S$. agalactiae (sete quartos mamários positivos), o isolamento de $S$. agalactiae só foi positivo em duas das três coletas (Quadro 5). Como pode ser observado, a coleta de mais de uma amostra contribuiu para melhorar a possibilidade de isolamentos destes agentes. Os resultados das amostras coletadas na plataforma de recepção da indústria também evidenciaram que o exame de mais de uma amostra permitiu identificar maior número de rebanhos positivos, tanto para $S$. aureus quanto para $S$. agalactiae (Quadros 2 e 3).

Alguns fatores que têm sido observados interferir com a sensibilidade do método são a diluição que ocorre quando todo o leite da fazenda é reunido, a quantidade de bactérias eliminadas pelas glândulas infectadas e o número de glândulas infectadas no rebanho (Godkin \& Leslie 1993). O padrão de eliminação dos agentes contagiosos da mastite pelas glândulas mamárias infectadas geralmente apresenta variabilidade, de modo que a análise de amostras consecutivas tem sido recomendada para aumentar a sensibilidade do exame (Sears et al. 1990, Bartlett \& Miller 1993, Farnsworth 1993, 1997, Godkin \& Leslie 1993). Por essa razão, tem sido recomendada a avaliação de amostras múltiplas e consecutivas, coletadas durante um período de tempo, para se considerar um rebanho isento desses agentes (Bartlett \& Miller 1993, Farnsworth 1993, Sears et al. 1993).

A presença de contaminantes esculina-positivos nas placas de ágar TKT pode prejudicar a identificação das colônias de $S$. agalactiae. Durante a execução do teste, na avaliação das culturas das amostras coletadas na plataforma de recepção da indústria, houve maior contaminação com Streptococcus sp esculina positivos, provavelmente de origem ambiental. A utilização de visualização sob luz ultra-violeta permitiu diferenciar melhor as colônias esculina negativas nessas condições. Este problema não ocorreu nas amostras dos rebanhos individuais, quando foram feitas diluições do leite. $\mathrm{O}$ meio de ágar sal manitol para $S$. aureus apresentou maior seletividade, fornecendo sempre menor número de colônias, de modo que foi mais fácil detectar colônias com as características desta espécie.

A contagem de células somáticas no leite total fornece uma indicação da mastite subclínica no rebanho. Os resultados obtidos dos 33 rebanhos amostrados na plataforma de recepção da indústria mostraram que 27 rebanhos $(81,2 \%)$ apresentaram contagens acima de 200.000 células $\mathrm{ml}^{-1}$. Níveis acima de $200.000 \mathrm{ml}^{-1}$ para o leite total têm sido considerados como sugestivos de infecção subclínica nos animais (Bramley et al. 1996). Contudo, os dados da contagem de células obtidos fornecem apenas uma indicação de inflama- 
ção e devem ser considerados com precaução, pois foi avaliada somente uma amostra em um único período de tempo. Sabe-se que, devido às flutuações normais observadas nas contagens de células somáticas durante o curso da infecção, há necessidade de exame de amostras periódicas, em um período de tempo maior (Reneau 1985, Vecht \& Wisselink 1990, Harmon, 1994).

Os resultados mostraram que o exame microbiológico do leite do tanque pode ser empregado nas condições brasileiras, desde que sejam obedecidos os critérios de uso de meios seletivos, coleta adequada da amostra, análise de pelo menos três amostras consecutivas e identificação criteriosa das espécies de microrganismos, especialmente com relação a $S$. aureus e $S$. agalactiae. Este método tem sido usado em outros países para monitoração de programas de controle da mastite e triagem de rebanhos especialmente para a mastite subclínica, causada por organismos contagiosos. Nesse caso recomenda-se o exame de amostras periódicas mensais (Bartlett et al. 1991, Edmondson 1993, Farnsworth 1993, Farnsworth 1997, Godkin \& Leslie 1993, Bramley et al. 1996). É também um método prático e menos dispendioso, pois possibilita a avaliação do conjunto de animais. A coleta do leite pode ser realizada diretamente nos rebanhos ou na plataforma de recepção da indústria, o que oferece a vantagem de permitir a triagem de rebanhos com rapidez e sem custos com o transporte. Além disso, se o exame é associado à contagem de células, fornece uma indicação mais precisa do estado de saúde do rebanho.

Embora o exame microbiológico do leite do tanque ofereça vantagens, é importante salientar que ele não substitui o exame de animais ou quartos mamários individuais no diagnóstico das infecções intramamárias. Pode ser considerado um instrumento útil para a monitorização de programas de controle de mastite, mas os resultados obtidos não podem ser usados para predizer o número de quartos mamários infectados no rebanho (González et al. 1986, Bartlett et al. 1991), e culturas negativas não oferecem a garantia da ausência dos agentes contagiosos da mastite.

A comparação dos resultados obtidos com amostras de quartos mamários individuais com as do leite do tanque evidencia a necessidade de maiores cuidados higiênicos durante o processo de ordenha. $O$ elevado número de amostras positivas para coliformes e leveduras isolados do leite do tanque, tanto dos rebanhos A, B, C e D, quanto da plataforma de recepção da indústria, indica deficiências no esquema de higienização e de obtenção e conservação do leite. Esses fatos e a alta incidência de $S$. aureus e $S$. agalactiae apontam para a necessidade de elaboração de políticas para o controle da mastite e de melhoria da qualidade higiênica do leite nas fazendas.

Agradecimentos.- A Marcos Aurélio Souto Silva pela colaboração nos exames microbiológicos e à Christian Hansen Indústria e Comércio Ltda, pela doação de reagentes e empréstimo do equipamento Fossomatic 90.

\section{REFERÊNCIAS}

Bartlett P.C. \& Miller G.Y. 1993. Mastitis microbiology: what is considered normal? Agri-Practice 14(6): 12-14.

Bartlett P.C., Miller G.Y., Lance S.E. \& Heider L.E. 1991. Use of bulk tank and milk filter cultures in screening for Streptococcus agalactiae and coagulasepositive Staphylococci. J. Food Protec. 54(11): 848-851.

Bramley A.J., Cullor J.S., Erskine R.J., Fox L.K., Harmon R.J., Hogan J.S., Nickerson S.C., Oliver S.P., Smith K.L. \& Sordillo L.M. 1996. Current Concepts of Bovine Mastitis. 4th ed. National Mastitis Council, Madison. 64p.

Cowan S. T. \& Steel K. J. 1974. Manual for the Identification of Medical Bacteria. Cambridge University Press, Cambridge. 238p.

Edmondson P.W. 1993. Bulk tank analysis - A useful foot in the door. Cattle Practice 1:133-139.

Farnsworth R.J. 1993. Microbiologic examination of bulk tank milk. Veterinary Clinics of North America: Food Animal Practice 9(3): 469-474.

Farnsworth R. J. 1997. Use of bulk tank cultures in problem solving and herd monitoring. Proc. Seminario Regional de Calidad de Leche, Country Club de Atlántida, Uruguay, p.139-141.

Godkin M.A. \& Leslie K.E. 1993. Culture of bulk tank milk as a mastitis screening test: a brief review. Can. Vet. J. 34:601-605.

González R.N., Jasper D.E., Bushnell R.B. \& Farver T.B. 1986. Relationship between mastitis pathogen numbers in bulk tank milk and bovine udder infections in California dairy herds. J. Am. Vet. Med. Assoc. 189(4):442-445.

Harmon R.J. 1994. Physiology of mastitis and factors affecting somatic cell counts. J. Dairy Sci. 77(7):2103-2112.

Harmon R. J., Eberhart R. J., Jasper D. E., Langlois B. E. \& Wilson R. A. 1990. Microbiological procedures for the diagnosis of bovine udder infection. National Mastitis Council, Arlington. 34p.

Hogan J.S., Pankey J.W., Murdough P. \& Howard D.B. 1986. Survey of bulk tank milk using blood-esculin agar counts. J. Food Protec. 49(12):990-993.

Higgs T.M. \& Bramley, A.J. 1981. Laboratory techniques for the examination of milk samples, p. 95-109. In: Bramley A.J., Dodd F.H. \& Griffin T.K. (ed) Mastitis control and herd management. Technical Bulletin 4, National Institute for Research in Dairying, Reading.

Martin S.W., Meek A.H. \& Willeberg P. 1994. Measurement of disease frequency and production, p. 48-76. In: Martin S.W., Meek A.H. \& Willeberg P. (ed.) Veterinary Epidemiology. Principles and Methods. Iowa State University Press, Ames.

Oz H.H., Hillmann D.J. \& Farnsworth R.J. 1985. Bulk tank milk analysis for isolating mastogenic bacteria. Dairy and Food Sanitation 5(7): 248-251.

Reneau J.K. 1985. Effective use of dairy herd improvement somatic cell counts in mastitis control. J. Dairy Sci. 69(6): 1708-1720.

Roberson J.R.; Fox L.K., Hancock D.D. \& Gay J.M. 1994. Ecology of Staphylococcus aureus isolated from various sites on dairy farms. J. Dairy Sci. 77(11):33543364.

Sears P.M., González R.N., Wilson D.J. \& Han H.R. 1993. Procedures for mastitis diagnosis and control. Veterinary Clinics of North America: Food Animal Practice 9(3):445-468.

Sears P.M., Smith B.S., English, P.B., Herer P.S. \& González R.N. 1990. Shedding pattern of Staphylococcus aureus from bovine intramammary infections. J. Dairy Sci. 73(10)2785-2789.

Vecht U. \& Wisselink H.J. 1990. Dutch national mastitis survey. The value of bulk milk cell counts in diagnosing bovine mastitis. Neth. Milk Dairy J. 44:83-88. 